Jan Polák

ORCID: https://orcid.org/0000-0003-4063-5695

Palacký University Olomouc, Czech Republic

\title{
Induced Abortion in the Contemporary Penitential Praxis of the Catholic Church. How to be an Instrument of New Hope*
}

\begin{abstract}
The aim of this paper is to consider how a priest could contribute to the healing of those who are burdened with the crime of induced abortion. The response of the Catholic Church towards this issue, throughout the centuries, deserves to be discussed on the basis of some relevant facts. The topic concerns not only moral theology and canon law but it is also the object of research of modern psychology. A confessor, confronted with procured abortion, should reflect seriously on which type of penance will be a real spiritual medicine for his penitent. This study would like to present some examples. It reflects the actual status quo in some selected dioceses concerning the forum internum. The paper will conclude with some proposals to address such situations.
\end{abstract}

\section{Keywords}

induced abortion, confession, tradition, foetus, trauma, penance.

This study is a result of the research funded by the Internal Grant Agency as the project IGA_CMTF_2019_005 “Christian and contemporary society”. 
So much has been said and written on this topic that it could seem redundant to add anything further. The aim of this paper is not to deal with this subject in particulars but rather to reflect about some aspects which are considered important in connection with the actual confessional praxis in the Catholic Church.

The problem of induced abortion is still a current issue. According to the statistics, 55.9 million induced abortions took place in the whole world every year between 2010 and 2014. From these estimated 56 million abortions 49.3 million occurred in developing regions and 6.6 million in developed countries. Although our region - Middle and Eastern Europe, experienced a very dynamic decrease in abortion rates (from 88 per 1,000 women aged 15-44 in 1990-1994 to 42 per 1,00o during 2010-2014), ${ }^{1}$ these rates are relatively still high. For example, in the Czech Republic, during the last 20 years between 20 and 30 thousand foetuses were aborted every year. ${ }^{2}$ The situation in the Slovak Republic is much better in this respect. In this land the statistical number of induced abortions decreased by more than a half in this period. ${ }^{3}$ This phenomenon does not only concern people without confession but it is also not rare to occur within the Catholic communities.

In the following reflection we would like to focus our attention precisely on the priestly confessional service. There are some good reasons why we should be concerned with this topic. First of all, the ethical problem of induced abortion is still on-going. Secondly, we are convinced that the Sacrament of Reconciliation plays a very important role in the process of healing after undergoing this intervention. Third, Pope Francis recently expressed his opinion on this issue several times. We can mention his speech during the General Audience on $10^{\text {th }}$ October 2018 when he used very expressive words comparing induced abortion to: "hiring a hit man to solve a problem"4.

But maybe the most important reason to consider this topic is the publishing of the papal apostolic letter Misericordia et Misera at the conclusion

${ }^{2}$ Cf. S. Singh et al., Abortion Worldwide 2017. Uneven Progress and Unequal Access, New York 2018, pp. 8-9.

2 In 2000, 32,530 interruptions of pregnancies occurred, in 2016 there were 20,406. Cf. Ústav zdravotnických informací a statistiky, Potraty 2016, Praha 2018, p. 13.

${ }^{3}$ There were noted 16,594 induced abortions in 2000, in 2017 only 7,496. Cf. Národné centrum zdravotníckych informácií, Potraty v Slovenskej republike 2017, Bratislava 2018, p. 9.

${ }^{4}$ Francis, Speech at the General Audience (Rome, October 10, 2018), http://w2.vatican.va/ content/francesco/en/audiences/2018/documents/papa-francesco_20181010_udienza-generale. html (14.03.2019). 
of the Extraordinary Jubilee on $20^{\text {th }}$ November 2016 in which the Holy Father empowers all priests in the world to lift the excommunication latae sententiae and to absolve the sin of a procured abortion. He states here: "I wish to restate as firmly as I can that abortion is a grave sin, since it puts an end to an innocent life. In the same way, however, I can and must state that there is no sin that God's mercy cannot reach and wipe away when it finds a repentant heart seeking to be reconciled with the Father. May every priest, therefore, be a guide, support and comfort to penitents on this journey of special reconciliation."

Pope Francis considers the sacrament of penance a very important step in the process of inner healing after a procured abortion. He also emphasizes the role of a priest that should accompany and mediate new hope to the penitent. But how shall he "support and comfort" the confessing person? And what kind of penance is to be imposed for such a specific issue? Before we try to answer these questions we will take a glance at the history of the Church in order to follow how it resolved this problem during the centuries.

\section{A brief look into the Tradition of the Church}

The Church, from its earliest history up to these days, always held the deliberate and direct abortion as a very serious sin and took a strict stand on this issue in its penal legislation. ${ }^{6}$ This position can be found since the early Christian works. ${ }^{7}$ The only thing which was debated through centuries was the question on whether a homicide automatically occurs in every stage of development of the embryo or whether there is a moment at which a human becomes a human. In other words, when, precisely, is the soul infused in the physical substrate, and a human becomes a person with the inviolable right of life? And in which cases

${ }^{5}$ Francis, Apost. let. Misericordia et Misera (November 20, 2016), n. 12.

${ }^{6}$ From the literature dealing with this topic see especially: R. J. Huser, The Crime of Abortion in Canon Law, Washington, DC 1942; J. T. Noonan Jr., Abortion and the Catholic Church: A Summary History, "Natural Law Forum" 12 (1967), pp. 85-131; G. Caprile, Non uccidere. Il Magistero della Chiesa sull'aborto, Roma 1981; E. Nardi, Procurato aborto nel mondo greco romano, Milan 1971; W. P. Müller, The Criminalization of Abortion in the West. Its Origins in the Medieval Law, Ithaca, NY 2012; Z. Mistry, Abortion in the Early Middle Ages. C. $500-$ 900, Rochester, NY - Suffolk 2015; W. P. Müller, Die Abtreibung. Anfängeder Kriminalisierung 1140-1650, Köln - Weimar - Wien 2000.

${ }^{7}$ E.g. Didache or Epistle of Barnabas. 
is an abortion a real homicide, and in which cases is it "only" a destruction of an inanimate cluster of cells? It is clear that the nature of the penance for an induced abortion is determined from the answers to these questions.

The distinction between a formed and an unformed foetus was grounded especially in two authorities. The first one was the Greek version (Septuagint) of Exodus 21:22-23 and the second one was Aristotle's teaching about matter and form. According to this teaching, a male foetus is animated, which means it gets an intellective soul, on the fortieth day after conception and a female one just on the eightieth day. A pregnant woman recognizes this moment after the movement of her child in the womb. But the same Aristotle confesses that there is no accuracy in these things. ${ }^{8}$

On the other hand, it was apparent, many times that there is a danger of a certain moral relativism in this distinction. So many authorities in the Church refused categorically, for several times, to take into account whether the foetus is formed and animated or not. One of these authorities was e.g. Tertullian $(\dagger 240) .{ }^{9}$

The punishment for an abortion entered in the jurisprudence of the Church with the Synod of Elvira in Spain (c. 300). Its Canon 63 states: "Si qua mulier per adulterium absente marito conceperit, idque post facinus occiderit, placuit ei nec in finem dandam esse communionem, eo quod geminaverit scelus." ${ }^{10}$

There is no general agreement among lawyers on how to understand the word communio. Some of them think that it refers only to the Holy Eucharist, others understand it as merely the sacramental absolution, and still others refer to the reconciliation and unity with the Church. ${ }^{11}$ If it is so or not so, all meanings of communion are connected together very closely.

${ }^{8}$ Cf. Aristotle, History of animals. Books VII-X, 583b, ed. and trans. D. M. Balme,

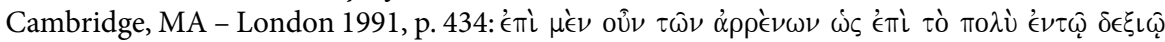

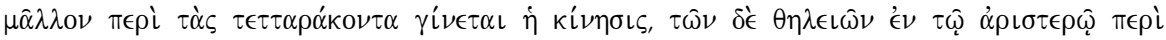

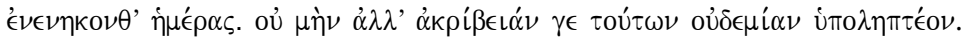

${ }^{9}$ Cf. Tertulliani, Apologeticus adversus gentes pro christianis 9, in: PL 1, 371-372: "Nobis vero, homicidio semel interdicto, etiam conceptum utero, dum adhuc sanguis in hominem delibatur, dissolvere non licet. Homicidii festinatio est prohibere nasci; nec refert natam quis eripiat animam, an nascentem disturbet: homo est, et qui est futurus; etiam fructus omnis jam in semine est."

\footnotetext{
${ }^{10}$ Concilium Eliberitanum, cap. LXIII, in: PL 1, 419.

${ }^{11}$ Cf. R. J. Huser, The Crime, pp. 17-18.
} 
The next council concerning abortion took place in Ancyra (314). It was conscious of severity of the Synod of Elvira and decided to soften the lifetime excommunication for ten years. ${ }^{12}$ The effect of this synod was enormous. Its declaration concerning abortion (can. 21) served as a text of reference for centuries, not only in the West, but also had an impact on the Eastern legislative works.

One of the writers who was influenced by this text in the East was St. Basil the Great (c. 330-379). He is apparently the first one who mentions among the sinners also all those who cooperate in induced abortion. ${ }^{13}$ In the first of his Three Canonical Letters he imposes the penance of ten years both to the women who underwent abortion ${ }^{14}$ and to the women who gave them a lethal poison. ${ }^{15}$ Nevertheless, as it results from the Greek text, he understands the penance as a medicine $\left(\theta \epsilon \rho \alpha \pi \epsilon^{\prime} \alpha\right)$ whose imposition should take account of the manner of repentance. ${ }^{16}$

The Synod of Lerida (524) brought forth other specifications. It mentions clerics involved in abortion for the first time. ${ }^{17}$ According to this synod, all who attempted to commit abortion are excommunicated for seven years and have to spend the rest of their life in penitence and humility. If it was a cleric he lost his ecclesiastical office for ever and after the repentance he could only sing in chorus. ${ }^{18}$

${ }^{12}$ Synod of Ancyra, can. 21, in: C. J. Hefele, A History of the Christian Councils, from the Original Documents, vol. 1: To the Close of the Council of Nicaea, A.D. 325, 2nd ed., ed. and

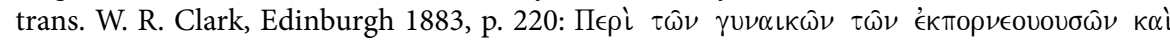

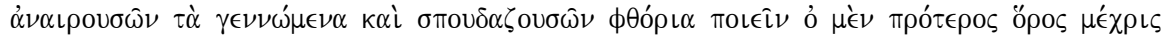

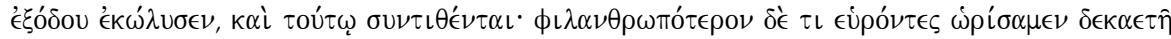

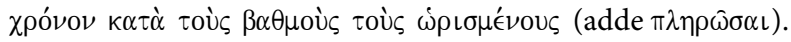

13

Cf. R. J. Huser, The Crime, 24.

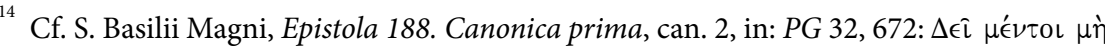

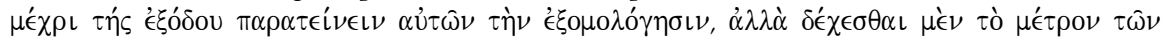

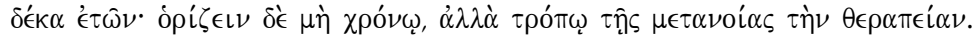

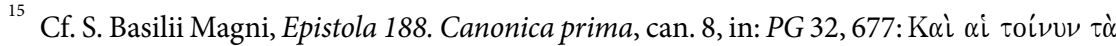

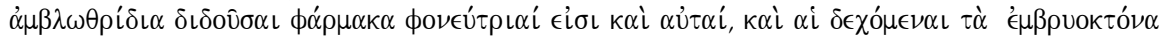
$\delta \eta \lambda \eta \tau \eta \dot{\rho}\llcorner\alpha$.

${ }^{16}$ Cf. S. Basilii Magni, Epistola 188. Canonica prima, can. 2, in: PG 32, 672.

${ }^{17}$ Cf. R. J. Huser, The Crime, 26.

${ }^{18}$ Concilium Ilerdense, can. 2, in: Sacrorum Conciliorum Nova, et Amplissima Collectio..., ed. J. D. Mansi, 8 vol., Parisiis 1901-1927, 612: "Hi vero qui male conceptos ex adulterio fotus vel editos necare studuerint, vel in uteris matrum potionibus aliquibus colliserint, in utroque sexu adulteris, post septem annorum curricula, communio tribuatur: ita tamen, ut omni tempore vitæ suæ fletibus et humilitati insistant. Si vero clerici fuerint, officium eis ministrandi 
The distinction between a formed (animated) and an unformed (unanimated) foetus was recognized in the assigning of penance in the following centuries. ${ }^{19}$ So we can find different penances for abortion in various medieval penitentials. They vary from one to ten years in the case that a sinner was a layman. ${ }^{20}$ If he was a cleric and the foetus was animated, the penalty was a canonical impediment (irregularity) which bared him from receiving and exercising holy orders. ${ }^{21}$ Also the famous Decree of Gratian (c. 1140) ${ }^{22}$ and the Summa Theologica of Thomas Aquinas $^{23}$ go in this direction. Nevertheless the moment of animation is either not indicated or the teaching of Aristotle is accepted. The penance for an abortion of a non-formed foetus was not so severe. According to some authors of the Decretals of Pope Gregory IX like Bernard de Bottone ( $\dagger 1266)$ or Cardinal Hostiensis ( $\dagger 1271)$, only a spiritual penance is to be imposed even if it was naturally considered a very serious $\sin ^{24}$

The Synod of Riez (1285) represents a further step forward. It promulgated that both abortion and murder are penalized with automatic excommunication.

recuperare non licet; attamen in choro psallentium a tempore receptæ communionis intersint. Ipsis veneficis in exitu tantum, si facinora sua omni tempore vitæ suæ defleverint, communio tribuatur."

${ }^{19}$ This distinction was definitely stopped by Pius IX only in 1869.

${ }^{20}$ Cf. J. T. Noonan Jr., Abortion, p. 98. E.g. Beda Venerabilis, Poenitentiale Bedae, c. 3, 12, in: Die Bussbücher und die Bussdisziplin der Kirche, ed. H. J. Schmitz, Mainz 1883, p. 560: "Mulier qui occidit filium suum in utero ante dies XL, I annum peniteat. Si vero post dies XL, III annos. Sed distat multum, utrum paupercula pro dificultate nutriendi an fornicaria causa sui sceleris celandi faciat."; Poenitentiale Bobiense, c. 32, in: Die Bussordnungen der abendländischen Kirche nebst einer rechtsgeschichtlichen Einleitung, ed. F. W. H. Wasserschleben, Halle 1851, p. 410: "Si quis mulier avorsum fecerit voluntarie, tres annos poeniteat, unum in pane et acqua"; Burchardi Wormaciensis Episcopi, Decretorum libri XX, 18, c. 60, in: PL 140, 934: "Si qua mulier abortum fecerit voluntarie, tribus annis pœniteat."

${ }^{21}$ This canonical punishment became obligatory in the whole church in 1211 when Innocent III issued a decree Sicut ex. Cf. J. R. Connery - L. S. Cahill, Abortion. Roman Catholic Perspectives, in: Bioethics, vol. 1, ed. Bruce Jennings, Farmington Hills, MI 2014, pp. 37-41 at 38.

${ }^{22}$ Gratiani, Decretum, pars II, ca. 32, q. 2, c. 8-10, in: PL 187, 1471-1472: "Non est homicida qui abortum procurat ante, quam anima corpori sit infusa."

${ }^{23}$ Sancti Thomae de Aquino, Summa theologiae, II-IIae, q. 64, a. 8, 3rd ed., Cinisello Balsamo, MI 1999, San Paolo, p. 1366: "Ad secundum dicendum quod ille qui percutit mulierem praegnantem dat operam rei illicitae. Et ideo si sequatur mors vel mulieris vel puerperii animati, non effugiet homicidii crimen."

${ }^{24}$ Cf. R. J. Huser, The Crime, 53. 
The absolution from it is reserved to the Holy See. ${ }^{25}$ The Council of Avignon (1326) transfers this reservation to the Bishop or his delegates. ${ }^{26}$

At the end of the $16^{\text {th }}$ century two papal constitutions dealing with the crime of abortion were issued: Effraenatam of Sixtus V in 1588 and Sedes Apostolica of Gregory XIV in 1591. They confirmed that the penalty for induced abortion is excommunication ipso facto reserved to the local ordinary for laymen and irregularity to receive or exercise the holy orders for clerics. ${ }^{27}$ These regulations ${ }^{28}$ became fonts for CIC $(1917)^{29}$ and also for the actual CIC (1983). ${ }^{30}$

${ }^{25}$ Concilium Regiense, can. 14, in:Sacrorum Conciliorum, 24, p. 581:"Item, quod quicumque alium toxicare aut opem adhibere, vel consilium dare, vel in necem alterius toxicum dictare, seu vendere, aut aliter ministrare præsumpserit, et herbas mortiferas in mortem vel abortivum cuiquam dederit, eo ipso excommunicationem incurrat, a qua nonnisi per Sedem Apostolicam absolvatur. Et si Clericus beneficiatus fuerit, illo sit privatus beneficio ipso facto, et ab ordine quem susceperat degradetur, tradendus curiæ sæculari."

${ }^{26}$ Cf. ConciliumAvenionense, c. 22, in: Sacrorum Conciliorum, 25, pp. 757-758.

${ }^{27}$ Sixtus V reaffirmed the Synod of Riez stating, that the absolution is reserved to the Holy See: Sixtus V, Const. Effraenatam (October 29, 1588), $₫ 8$, in: Codicis Iuris Canonici Fontes, vol. 1: Concilia Generalia - Romani Pontifices usque ad anum 1745, ed. P. Card. Gasparri, Romae 1947, n. 165: "ne cum iis Clericis, qui huiusmodi delicta perpetraverint, etiamsi eorum crimen occultum fuerit, super irregularitate praemissorum occasione contracta, nec per locorum Ordinarios, nec per alios quavis auctoritate fungentes, quam per Nos, et Rom. Pontif. nostros Successores, et tunc non nisi urgentissimis de causis dispensari possit. Ac tam absolvendi, quam dispensandi facultatem huiusmodi etiam quoad forum conscientiae in casibus superius expressis, Nobis, et Successoribus nostris dumtaxat reservamus". Gregory XIV returned the reservation to the local ordinary: Gregory XIV, Sedes Apostolica (Mai 31, 1951), \$2, in: ibid., n. 173: "quilibet Presbyter, tam saecularis, quam cuiusvis Ordinis regularis ad Christifidelium confessiones audiendas, et ad hos casus specialiter per loci Ordinarium deputatus, plenam, et liberam in foro conscientiae tantum, absolvendi habeat facultatem."

${ }^{28}$ It is still necessary to say that in 1869 Pius IX issued the constitution Apostolicae Sedis in which the magisterium of the Church stops distinguishing between a formed and an unformed foetus. The excommunication is to be imposed only to those who really accomplished the abortion, not only attempted it: Pius IX, Apostolicae Sedis (June 29, 1868), § 3.2, in: Codicis Iuris Canonici Fontes, vol. 3: Romani Pontifices. A. 1867-1917, ed. P. Card. Gasparri, Romae 1933, n. 552: "procurantes abortum, effectu sequuto".

${ }^{29}$ Codex Iuris Canonici..., c. $9854^{\circ}$, ed. P. Gasparri, Romae 1918,pp. 281-282: "Sunt irregulares ex delicto: Qui voluntarium homicidium perpetrarunt aut foetus humani abortum procuraverunt, effectu secuto, omnesque cooperantes". Ibid., c. $2350 \$ 1$, p. 642: "Procurantes abortum, matre non excerpta, incurrunt, effectu secuto, in excommunicationem latae sententiae Ordinario reservatam; et si sint clerici, praeterea deponantur."

${ }^{30}$ Cf. c. $1398,10414^{\circ}$ and $1044 \$ 13^{\circ} \mathrm{CIC}$. 
The contemporary documents of the Church, going in the same direction, condemn induced abortion very clearly. ${ }^{31}$ But how to help people who aborted but who deeply regret this decision; who are in despair, who would like to begin to live with new hope, and how a priest should accompany them in the process of healing. Before focusing on these questions let's look at the current canon law, especially at the conditions of punishments connected with induced abortion.

\section{The penalty of excommunication latae sententiae}

According to c. $1398 \mathrm{CIC}$, everyone who procures abortion incurs excommunication ipso facto. But it is necessary to say that this does not occur in every situation. There are in fact some circumstances that liberate from this penalty (c. 1324 CIC). For example if somebody did not know at the moment of abortion that this act is automatically connected with excommunication (c. $1324 \$ 19^{\circ} \mathrm{CIC}$ ) or if the decision was motivated by grave fear, necessity or serious inconvenience (c. $1324 \$ 15^{\circ} \mathrm{CIC}$ ) the person does not incur this penalty ${ }^{32}$ and that is why it is not necessary to absolve him or her of it.

Even if the person incurs it, the penalty should not be understood as a vengeance of the Church for inappropriate behaviour. It has more likely the character of a medicine (c. $1312 \$ 11^{\circ} \mathrm{CIC}$ ) although we can also speak about its pedagogical or preventive dimension. Its main aim is to contribute to the spiritual recuperation of the person. It should not imprint a negative stigma upon the penitent forever.

There is no need to remind the person that induced abortion bears a very heavy burden for every right formed conscience. It is not easy to break free

${ }^{31}$ See e.g.: Pius XI, Enc. let. Casti connubii (December 31, 1930), nn. 63-67; Vatican Council II, Past. const. Gaudium et spes (December 7, 1965), n. 51; Paul VI, Enc. let. Humanae vitae (July 25, 1968), n. 14; Congregation for the Doctrine of the Faith (= CDF), Declaration on Procured Abortion (November 18, 1974); CDF, Inst. Donum vitae (February 22, 1987), I. 1; Catechismus Caholicae Ecclesiae, Città del Vaticano 1997, nn. 2270-2273; CDF, Inst. Dignitas personae (September 8, 2008), n. 23.

32 Cf. J. Sanchis, Laborto procurato: aspetti canonistici, "Ius ecclesiae. Rivista internazionale di Diritto canonico" 1 (1989), pp. 663-677 at 674. 
from it. In most cases it is a process for a longer period which requires spiritual accompaniment. The person who procured abortion can also be afflicted by different psychological disorders, described by one term: post-abortion trauma. If it is so, cooperation with a professional in the area of psychology or psychiatry is highly recommended.

\section{Post-abortion trauma}

If we searched for "post-abortion syndrome" in different books of gynecology, obstetrics or sexology we would not find any remark ${ }^{33}$ or we would find only a very short explanation ${ }^{34}$ or a statement that such a term is only fiction. ${ }^{35}$ The problem is what we understand by this term. A medical dictionary defines a syndrome as a: "combination of symptoms of a certain disease."36

However an induced abortion does not necessarily provoke negative consequences in every woman. It could be that some of them feel relief from an easy and quick solution of an unenviable situation. Others will feel the hard pricks of conscience only after many years or maybe not at all. This was a reason, besides other (political) ones, why this term does not appear in the Diagnostic and Statistical Manual of Mental Disorders (=DSM) of the American Psychiatric Association. ${ }^{37}$ We can find only "post-traumatic stress disorder" here which is a wider term that includes also other traumatic events. There are lots of women that show traumatic symptoms after undergoing an induced abortion. Nevertheless, each of them becomes reconciled to it in a different way depending on her personality. It seems to be better to use the term "post-abortion trauma". The induced abortion can indeed function as a trigger of a set of objective psychological

${ }^{33}$ Cf. R. Pilka et al., Gynekologie, Praha 2017.

${ }^{34}$ Cf. A. Roztočil, Poruchy v prvním trimestru těhotenství, in: Aleš Roztočil et al., Moderní gynekologie, Praha 2011, pp. 203-221 at 215.

${ }^{35}$ Cf. P. Čepický, Antikoncepce a ostatní metody plánovaného rodičovství, in: Petr Weiss et al., Sexuologie, Praha 2010, pp. 275-293 at 292-293.

${ }^{36}$ Cf. syndrom, in: M. Vokurka - J. Hugo et al., Velký lékařský slovník, 9th ed., Praha 2009, p. 1006.

${ }^{37}$ Current version: American Psychiatric Association, Diagnostic and Statistical Manual of Mental Disorders, 5th ed., Arlington, VA 2013. 
disorders ${ }^{38}$ even if some scientists in this area suggest that it only worsens a pre-existing disordered neuro-psychical condition. ${ }^{39}$

What symptoms can a woman present after an induced abortion? The hallmark of the post-abortion trauma is a biphasic cycle of re-experience and an attempt of avoidance.

The persistent re-experience occurs when a person attempts to master a traumatic event experienced in his/her life. It can include recurrent images, thoughts, dreams, illusions, flashbacks during waking states and horrific nightmares during sleep, or a sense of reliving the experience as if it were present now. It is clear that such a person will come to lead an emotional and very impoverished life. ${ }^{40}$

Attempting to regulate the overwhelming effect, the afflicted person tries to dissociate painful memories from ordinary awareness. It could happen through distancing oneself from thoughts, feelings, conversations, activities, places and people that remind them of the traumatic event. So the trauma victim is caught between amnesia and reliving the trauma, between arid states of no feeling and floods of overwhelming feeling, between complete inhibition of action and impulsive action.

Another important symptom of a traumatic event is hyper arousal. A person startles easily, reacts irritably and sleeps poorly. He or she is like in a permanent alert status. This hyper vigilance requires a lot of psychic energy and it makes a normal life quasi impossible. ${ }^{41}$

It is also important to say that post-abortion trauma can afflict not only women who aborted but also their men, partners or other family members, and also the medical staff that carried out the intervention or assisted with it. ${ }^{42}$

${ }^{38}$ Cf. J. Aznar - G. Cerdá, Abortion and Women's Mental Health, in: Pontifical Academy for Life, Post-Abortion Trauma. Possible Psychological and Existential Aftermaths, Rome 2014, pp. 195-210 at 207.

${ }^{39}$ Cf. A. Roztočil, Poruchy, p. 215.

${ }^{40}$ Cf. V. M. Rue, Clinical Dimensions of Post-Abortion Trauma, in: Pont. Ac. for Life, PostAbortion Trauma, pp. 19-146 at 60-61.

${ }^{41}$ Cf. V. M. Rue, Clinical, pp. 62-63. Other ways how the post-abortion trauma manifests itself can be found in: L. Freed - P. Y. Salazar, A Season to Heal. Help and Hope for Those Working Through Post-Abortion Stress, Nashville, TN 1996, pp. 1-12; Myriam... warum weinst Du? Die Leiden der Frauen nach der Abtreibung, Uznach 1996, pp. 80-97; K. Lamplmair et al., Ich nannte sie Nadine. Informationen und Hilfe vor und nach einem Schwangerschaftsabbruch von Ärzten, Psychologen und Betroffenen, 5th ed., Bad Leonfelden 2016.

${ }^{42}$ From the literature dealing with men see e.g.: R. Karbiner - F. Kobler, Betriebsanleitung für den Mann. Warum das starke Geschlecht nicht stark sein muss, Linz 2011; C. T. Coyle, Men 


\section{How to treat induced abortion in the sacramental forum?}

The way induced abortion was dealt with in the Tradition of the Church might be considered too harsh today: no communion for the rest of the penitent's life or for at least ten years, three years penitence on bread and water or also excommunication latae sententiae. These sorts of penance evoke or can evoke certain embarrassment among contemporary people.

Nowadays we are more knowledgeable about the possible psychological and existential aftereffects which an induced abortion can provoke especially about how deeply afflicted a woman who aborted can be. On the other hand, it is not possible to impose only a very simple penance in the conviction that the penitent learned a lesson from it by him- or herself. We must not forget that St. Basil the Great considered a penance as a means of healing. In fact, the actual Ordo paenitentiae speaks about it in this sense. ${ }^{43}$ So, which penance should a priest impose for induced abortion, so that it may be a real medicine which will pour new hope into a desperate penitent?

Certain guidelines can be found in Evangelium vitae, n. 99 where John Paul II expresses comprehension and sympathy for women who have aborted. He is conscious that they were forced to do that through unfavourable circumstances in a lot of cases and he gives them the following advice: "But do not give in to discouragement and do not lose hope. Try rather to understand what happened and face it honestly. If you have not already done so, give yourselves over with humility and trust to repentance. The Father of mercies is ready to give you his forgiveness and his peace in the Sacrament of Reconciliation. You will come to understand that nothing is definitively lost and you will also be able to ask forgiveness from your child, who is now living in the Lord. With the friendly and expert help and advice of other people, and as a result of your own painful experience, you can be among the most eloquent defenders of everyone's

and Abortion. Finding Healing, Restoring Hope, New Haven, CT 2009.

${ }^{43}$ Rituale Romanum ex Decreto Sacrosancti Ecumenici Concilii Vaticani II Instauratum Auctoritate Pauli II PP. VI Promulgatum. Ordo poenitentice, Editio Typica, Città del Vaticano 1974, p. 13: "Vera conversio per culparum satisfactionem, per vitæ emendationem necnon damni reparationem completur. Opus ac mensura satisfactionis debent unicuique pænitenti convenire, ut unusquisque ordinem quem læserat restauret, et pro morbo quo laboravit, contraria medicina curetur. Oportet proinde ut pœna sit revera remedium peccati et vitam aliquomodo renovet. Ita pænitens ea 'quæ retro quidem sunt obliviscens' (Phil 3,13) se noviter in mysterium salutis inserit et ad ea quæ sunt futura se extendit.” 
right to life. Through your commitment to life, whether by accepting the birth of other children or by welcoming and caring for those most in need of someone to be close to them, you will become promoters of a new way of looking at human life." ${ }^{44}$

In addition to this very important text we can find some very concrete advice in several documents of the American Bishops Conference. In most of the American dioceses Project Rachel exists for several decades. It's a Catholic program, in which experts in different areas (psychology, pastoral accompaniment, etc.) collaborate. Their common goal is to help the afflicted persons to get well. We can find very useful concrete observations of what a priest should be mindful of during the Sacrament of Reconciliation in the American Manual for Priests. ${ }^{45}$ We would like to mention some of them.

It's important, at first that the priest may assure the person of the existence of hope for him or her of God's love and so that he may lend an ear to him or her. It could be that the penitent will speak for a very long time. But the priest must realize that this is a very important component of the process of healing. After the absolution from the censure, if the penitent incurred it, he administers the absolution of the sin to the penitent. ${ }^{46}$ Concerning the penance: it should be life-affirming and have clear parameters and a definite end. Women who aborted could be scrupulous and they will be fearful that God will not have mercy on them if they did not carry out the penance accurately. ${ }^{47}$

\section{The types of penance}

The American manual Project Rachel Ministry suggests the following types of penance for a woman who aborted: a prayer (e.g. a Rosary, a Chaplet of

${ }^{44}$ John Paul II, Enc. let. Evangelium vitae (March 25, 1995), n. 99, Città del Vaticano 1995. See also AAS 87 (1995), pp. 515-516. The Latin version evinces some dissimilarities from this English translation.

${ }^{45}$ United States Conference of Catholic Bishops (= USCCB), Project Rachel Ministry. A PostAbortion Resource Manual for Priests and Project Rachel Leaders, Washington, DC 2009. An older version exists also in a German translation: Amerikanische Bischofskonferenz, Für Priester. Die Heilung der Abtreibungswunden, Wien 2006. Orig.: Post-AbortionMinistry. A Resource Manual for Priests, trans. M. Schöllbauer, Washington, DC 1999.

\footnotetext{
${ }^{46}$ Cf. USCCB, Project Rachel, pp. 10-11.

${ }^{47}$ Cf. ibid., p. 11.
} 
Divine Mercy or a fixed number of prayers) for others involved in the induced abortion; offering a weekday Mass for the aborted child or for the healing of the family; meditation of some Scripture passages like Luke 13:11-13; Luke 8:43-48; Luke 7:36-50, John 4:7-42, John 8:2-11, Psalm 51, Psalm 103; to be a volunteer in a charity activity for a special period with the goal to focus away from herself and to increase her feelings of self-worth as a child of God..$^{4}$

Apart from all the above the priest can also offer the participation in a memorial service for aborted or miscarried children. ${ }^{49}$ This can be an important part of the process of healing. A good healing practice for a woman who aborted to come to an inner peace could also be a suggestion that she should write a letter to God including all the things she would like to tell her child and then ask God to share them with her child.

We asked about 30 priests in different dioceses in Europe and in the world on whether they have any diocesan guidelines. Most of them informed us that they do not have any guidelines available..$^{50}$ We found some exceptions which we would like to present:

According to the official bulletin of the Archdiocese of Sarajevo (Bosnia and Herzegovina) Vrhbosna the penance could involve fasting, material aid to poor families, regular receiving of the Sacraments connected with the corresponding lifestyle. The confessor could also retain the absolution, if he considers it pastorally prudent, or he can recommend the praying of the Rosary or other prayers as a penance. ${ }^{51}$

In the Archdiocese of Olomouc (Czech Republic) there was praxis, until the publishing of Misericordia et misera, that a penitent, before the absolution, had to make a brief general confession and confess all sins committed in the last year at least. During the confession, a confessor should also explain to the person that the induced abortion is a very serious sin against life..$^{52}$ After Misericordia et misera the penitent did not have the duty of a brief general confession any

${ }^{48}$ Cf. ibid., p. 11.

${ }^{49}$ Some useful ideas for its realization can be found in: USCCB, Project Rachel, pp. 45-51.

${ }^{50}$ E.g. the Diocese of Austin, TX; Haarlem-Amsterdam; Žilina; Eichstätt; Seoul; Salzburg, Brixen-Bolzen; Łódź; Mainz or missionary area of Japan.

${ }^{51}$ Cf. V. Puljić, Odrješenje od cenzure i grijeha pobačaja, "Vrhbosna” 3 (1991), pp. 143-144.

52 Cf. Sine auctore, Absoluce od exkomunikací, "Acta Curiæ Archiepiscopalis Olomucensis" 2 (1998), p. 14. 
more but the priest should help him or her to take a look at the whole setting of his or her Christian life. ${ }^{53}$

The Archbishop of Turin (Italy), Cesare Nosiglia, recommends as a sacramental penance, imploring prayer during a regular participation at Holy Mass also on weekdays - for a certain period of time in accordance to the possibilities of a penitent; supporting of a Baby Centre or a project for the good of the little ones; being available to those who ponder an induced abortion both with counsel and with material help. Nosiglia speaks also about the importance of stable conversion..$^{54}$

Now we would like to present some interesting recommendations of confessors from different countries. They wanted to remain anonymous:

A priest from the Diocese of Austin (Texas - USA): asks the woman to name the child whom she aborted and to ask that child to pray for her. She can also pray for changing of laws in the United States; offer some financial support to Project Rachel or other programs for healing after abortion; become a volunteer in such a program and to help other women with counsel. If it is not too difficult for her she can go in front of a maternity clinic and to pray there for unborn children.

A priest from the Diocese of Žilina (Slovak Republic): "There is a non-written rule in our country to impose the Nine First Fridays devotion for the sin of the induced abortion".

A priest from the Diocese of Mainz (Germany) recommends a pilgrimage to a sanctuary of the Virgin Mary. If a woman consents she can also participate on a part of the pilgrimage to Santiago de Compostela. A good penance could also be a long-distance adoption of a child (e.g. by means of Misereor, Adveniat, Caritas, etc.), a financial assistance for an orphanage, a self-denial in a certain area, a stronger fasting - especially in Lent, a weekly adoration of the Blessed Sacrament or a daily prayer of a decade of the Rosary for a certain period of time.

We can also find some good advice in the speech of Pope Francis during the press conference on the way back from Panama on $27^{\text {th }}$ January 2019. According to the Holy Father, women who aborted are not only to be absolved from their sin but also to be accompanied by their spiritual guide for a certain time. They

${ }^{53}$ Cf. J. Graubner, Zpovědní fakulta, "Acta Cur. Arch. Olom." 1 (2017), p. 1.

${ }^{54}$ Cf. C. Nosiglia, Concessione della facoltà di rimettere la scomunica annessa al delitto dellaborto procurato senza l'onere del ricorso (Febbraio 18, 2015), https://www.sindone.org/ diocesitorino/allegati/53429/Decreto\%20Arcivescovo\%20-\%20remissione\%20della\%20 scomunica\%20aborto\%20procurato\%20-\%20Ostensione\%202015.pdf (01.04.2019). 
should experience comfort and mercy in the confessional. It happens often that they feel a need to meet their child. Pope Francis gives them the advice that they should talk to their child who is in heaven and to sing a lullaby to him or her. A woman can find in this some reconciliation with their child. But she must work this drama through..$^{55}$

\section{Our recommendations}

The Western Society represents a culture in which it is still a taboo to speak about emotions and feelings after an induced abortion - at least in public. This topic is an ideologically and politically burdened theme. For many women, this situation takes away the possibility of mourning their lost offspring, of working this issue through and of an inner healing.

If a woman visits a gynecologist confessing that they suffer serious psychological troubles after the intervention, a common reaction of this doctor is that this was her decision. It is surely true, at least officially. Nevertheless, there are usually so many factors that make the decision de factoun free.

The process of healing is usually a long haul. Apart from spiritual accompaniment the help of an expert in psychotherapy could be necessary. John Paul II advises the women to: "understand what happened and face it honestly." ${ }^{36}$ The root of their trouble is often the realization that the aborted foetus was a living human being after all, and the question about what to do after it had been massacred with their own consent in a terrible way, and the fact that it does not have a grave now.

A very liberating and healing element could be a "funeral ritual". Even if a woman does not properly dispose of the corporal remains of her child, she can always do something like a substitute burial. She can make a small coffin for her descendant, write his or her name on a paper, put it into the coffin and bury it in the presence of her dearest persons in the family grave. The best time for this ritual could be the $2^{\text {nd }}$ November when the Church prays for All Souls. The ritual can also include lighting a candle and laying a bunch of flowers down

${ }^{55}$ Cf. Francis, Conferenza stampa del Santo Padre durante il volo di ritorno da Panama (January 27, 2019), http://w2.vatican.va/content/francesco/it/speeches/2019/january/ documents/papa-francesco_20190127_panama-volo-ritorno.html (01.04.2019).

${ }^{56}$ John Paul II, Enc. let. Evangelium vitae (March 25, 1995), n. 99. 
on the grave. We believe that such a practice could also be proposed to the woman as a penance during the Sacrament of Reconciliation.

\section{Conclusion}

The Sacrament of Reconciliation represents an important rite de passage that helps the person to come to terms with the past, to take distance from the sin and to begin a new life full of hope. It is important that both the confessor and the penitent dedicate sufficient attention to this sacrament and that they celebrate it in the best way possible: according to the actual rite with all components and with an appropriate devoutness. To argue that the issue now concerns large numbers of people and thus it is legitimate to get it over very quickly, can be perceived as hurtful, disrespectful and cause other psychological and spiritual damage.

\section{Bibliography}

American Psychiatric Association, Diagnostic and Statistical Manual of Mental Disorders, 5th ed., Arlington, VA 2013.

Amerikanische Bischofskonferenz, Für Priester. Die Heilung der Abtreibungswunden, Wien 2006.

Aristotle, History of animals. Books VII-X, ed. and trans. D. M. Balme, Cambridge, MA - London 1991.

Aznar J. - Cerdá G., Abortion and Women's Mental Health, in: Pontifical Academy for Life, Post-Abortion Trauma. Possible Psychological and Existential Aftermaths, Rome 2014, pp. 195-210.

Beda Venerabilis, Poenitentiale Bedae, in: Die Bussbücher und die Bussdisziplin der Kirche, ed. H. J. Schmitz, Mainz 1883.

Burchardi Wormaciensis Episcopi, Decretorum libri XX, in: PL 140.

Caprile G., Non uccidere. Il Magistero della Chiesa sull'aborto, Roma 1981.

Catechismus Caholicae Ecclesiae, Città del Vaticano 1997.

Čepický P., Antikoncepce a ostatní metody plánovaného rodičovství, in: Petr Weiss et al., Sexuologie, Praha 2010, pp. 275-293.

Codex Iuris Canonici, Città del Vaticano 1983.

Codex Iuris Canonici, ed. P. Gasparri, Romae 1918.

Concilium Avenionense, in: Sacrorum Conciliorum Nova, et Amplissima Collectio..., ed. J. D. Mansi, vol. 25, Parisiis 1901-1927. 
Concilium Eliberitanum, in: $P L 1$.

Concilium Ilerdense, in: Sacrorum Conciliorum, vol. 8.

Concilium Regiense, in: Sacrorum Conciliorum, vol. 24.

Congregation for the Doctrine of the Faith, Declaration on Procured Abortion (November 18, 1974).

Congregation for the Doctrine of the Faith, Inst. Dignitas personae (September 8, 2008).

Congregation for the Doctrine of the Faith, Inst. Donum vitae (February 22, 1987).

Connery J. R. - Cahill L. S., Abortion. Roman Catholic Perspectives, in: Bioethics, vol. 1, ed. Bruce Jennings, Farmington Hills, MI 2014, pp. 37-41.

Coyle C. T., Men and Abortion. Finding Healing, Restoring Hope, New Haven, CT 2009.

Francis, Apost. let. Misericordia et Misera (November 20, 2016).

Francis, Conferenza stampa del Santo Padre durante il volo di ritorno da Panama (January 27, 2019), http://w2.vatican.va/content/francesco/it/speeches/2019/january/documents/papa-francesco_20190127_panama-volo-ritorno.html (01.04.2019).

Francis, Speech at the General Audience, (Rome, October 10, 2018), http://w2.vatican.va/ content/francesco/en/audiences/2018/documents/papa-francesco_20181010_udienzagenerale.html (14.03.2019).

Freed L. - Salazar P. Y., A Season to Heal. Help and Hope for Those Working Through Post-Abortion Stress, Nashville, TN 1996.

Gratiani, Decretum, in: PL 187.

Graubner J., Zpovědnífakulta, “Acta Curiæ Archiepiscopalis Olomucensis” 1 (2017), p. 1.

Gregory XIV, Sedes Apostolica (Mai 31, 1951), in: Codicis Iuris Canonici Fontes, vol. 1: Concilia Generalia - Romani Pontifices usque ad anum 1745, ed. P. Card. Gasparri, Romae 1947.

Huser R. J., The Crime of Abortion in Canon Law, Washington, DC 1942.

John Paul II, Enc. let. Evangelium vitae (March 25, 1995), Città del Vaticano 1995.

Karbiner R. - Kobler F., Betriebsanleitung für den Mann. Warum das starke Geschlecht nicht stark sein muss, Linz 2011.

Lamplmair K. et al., Ich nannte sie Nadine. Informationen und Hilfe vor und nach einem Schwangerschaftsabbruch von Ärzten, Psychologen und Betroffenen, 5th ed., Bad Leonfelden 2016.

Mistry Z., Abortion in the Early Middle Ages. C. 500 -900, Rochester, NY 2015, Boydell \& Brewer - Suffolk 2015.

Müller W. P., Die Abtreibung. Anfänge der Kriminalisierung 1140-1650, Köln - Weimar - Wien 2000.

Müller W. P., The Criminalization of Abortion in the West. Its Origins in the Medieval Law, Ithaca, NY 2012.

Myriam... warum weinst Du? Die Leiden der Frauen nach der Abtreibung, Uznach 1996.

Nardi E., Procurato aborto nel mondo greco romano, Milan 1971. 
Národné centrum zdravotníckych informácií, Potraty v Slovenskej republike 2017, Bratislava 2018.

Noonan J. T. Jr., Abortion and the Catholic Church: A Summary History, "Natural Law Forum" 12 (1967), pp. 85-131.

Nosiglia C., Concessione della facoltà di rimettere la scomunica annessa al delitto dell'aborto procurato senza l'onere del ricorso (Febbraio 18, 2015), https://www.sindone. org/diocesitorino/allegati/53429/Decreto\%20Arcivescovo\%20-\%20remissione\%20 della\%20scomunica\%20aborto\%20procurato\%20-\%20Ostensione\%202015.pdf (01.04.2019).

Paul VI, Enc. let. Humanae vitae (July 25, 1968).

Pilka R. et al., Gynekologie, Praha 2017.

Pius IX, Apostolicae Sedis (June 29, 1868), in: Codicis Iuris Canonici Fontes, vol. 3: Romani Pontifices. A. 1867-1917, ed. P. Card. Gasparri, Romae 1933.

Pius XI, Enc. let. Casti connubii (December 31, 1930).

Poenitentiale Bobiense, in: Die Bussordnungen der abendländischen Kirche nebst einer rechtsgeschichtlichen Einleitung, ed. F. W. H. Wasserschleben, Halle 1851.

Puljić V., Odrješenje od cenzure i grijeha pobačaja, "Vrhbosna” 3 (1991), pp. 143-144.

Rituale Romanum ex Decreto Sacrosancti Ecumenici Concilii Vaticani II Instauratum Auctoritate Pauli II PP. VI Promulgatum. Ordo pænitentioe, Editio Typica, Città del Vaticano 1974.

Roztočil A., Poruchy v prvním trimestru těhotenství, in: Aleš Roztočil et al., Moderní gynekologie, Praha 2011, pp. 203-221.

Rue V. M., Clinical Dimensions of Post-Abortion Trauma, in: Pontifical Academy for Life, Post-Abortion Trauma, pp. 19-146.

S. Basilii Magni, Epistola 188. Canonica prima, in: PG 32.

Sanchis J., L'aborto procurato: aspetti canonistici, "Ius ecclesiae. Rivista internazionale di Diritto canonico" 1 (1989), pp. 663-677.

Sancti Thomae de Aquino, Summa theologiae, 3rd ed., Cinisello Balsamo, MI 1999.

Sine auctore, Absoluce od exkomunikací, "Acta Curiæ Archiepiscopalis Olomucensis" 2 (1998), p. 14.

Singh S. et al., Abortion Worldwide 2017. Uneven Progress and Unequal Access, New York 2018.

Sixtus V, Const. Effraenatam (October 29, 1588), in: Codicis Iuris Canonici Fontes, vol. 1: Concilia Generalia - Romani Pontifices usque ad anum 1745, ed. P. Card. Gasparri, Romae 1947.

Syndrom, in: M. Vokurka - J. Hugo et al., Velký lékařský slovník, 9th ed., Praha 2009, p. 1006.

Synod of Ancyra, in: C. J. Hefele, A History of the Christian Councils, from the Original Documents, vol. 1: To the Close of the Council of Nicoea, A.D. 325, 2nd ed., ed. and trans. W. R. Clark, Edinburgh 1883. 
Tertulliani, Apologeticus adversus gentes pro christianis, in: PL 1.

United States Conference of Catholic Bishops, Project Rachel Ministry. A Post-Abortion Resource Manual for Priests and Project Rachel Leaders, Washington, DC 2009.

Ústav zdravotnických informací a statistiky, Potraty 2016, Praha 2018.

Vatican Council II, Past. const. Gaudium et spes (December 7, 1965). 